\title{
Global Apartheid: A Postscript
}

\author{
Anthony H. Richmond
}

\begin{abstract}
Trends in the numbers and location of refugees and asylum seekers during the 1980 and the 1990 are compared. The question of whether the world has created a system of "global apartheid" is reviewed. The outcome of asylum applications filed in European countries is compared with those in Canada and the United States. It is concluded that racism still prevails in the treatment of refugees. Canada's record compares favourably with those of other developed countries, although the main burden of refugee protection still falls on less developed regions of the world.
\end{abstract}

\section{Résumé}

Cet article compare les tendances contenues dans le nombre et la localisation géographique de réfugiés et de demandeurs d'asile pendant toute la période des années 80 et 90 . Il passe en revue la question de savoir si notre monde a crée un système d' "apartheid global ». Il compare aussi les suites données aux demandes d'asile soumises dans des pays européens et celles soumises au Canada et aux États-Unis. La conclusion tirée est que le racisme prévaut toujours dans le traitement réservé aux réfugiés. La performance du Canada se compare favorablement avec celle d'autres pays développés, bien que le gros $d u$ fardeau de la protection des réfugiés pèse toujours sur les régions les moins développées du monde.

\section{Introduction}

rising out of an examination of refugee policies and $A$ procedures in the decade of the 1980s, and up to 1 the early 1990s, the question was asked, "[A]re we creating a system of global apartheid based on discrimination against migrants and refugees from poorer developing countries?"' Subsequently, Aiken repeated the question. She examined the issue of racism in Canadian refugee policy and concluded that Canada was still "quite far from the vision of an anti-racist refugee program." ${ }^{2}$ This article contrasts selected elements of the refugee regime in Canada with those of European countries. The 1980 are compared with the 1990s.

First, it is necessary to note the changing size, character, and composition of refugee movements in recent years.

\section{Trends in Refugee Movements}

In 1989, the UNHCR recorded approximately 15 million refugees, of whom 4.6 million were located in Africa, 6.7 million in Asia, 1.2 million in Latin America and the Caribbean, and 1.4 million in North America (including 447,000 in Canada). The total in Europe was 788,720 . The total rose to 18 million in 1992, the largest increase being in Europe, which then reported over 3 million refugees and asylum applicants. By the end of 1999, the UNHCR identified 11.68 million refugees and an additional 10.58 million "others of concern," of whom approximately 1.2 million were currently asylum seekers. The overall distribution at the end of 1999 is shown in table 1.

In its annual report, the UNHCR noted that "1999 was one of the most challenging years in UNHCR's history. Conflicts in Kosovo, East Timor, and Chechnya dominate the daily headlines and many of UNHCR's resources, but there were 'forgotten' humanitarian cries around the world, especially in Africa."' 3 More than half a million new asylum applications were lodged in the main industrialized countries in 1999, an increase of 21 per cent over the previous year, giving rise to growing concern over humanitarian 


\section{Table 1: Refugees and Others of Concern to the UNHCR Population End 1999}

\begin{tabular}{|c|c|c|c|c|c|c|c|}
\hline $\begin{array}{r}\text { Region of } \\
\text { Asylum/ } \\
\text { Residence }\end{array}$ & Refugees & $\begin{array}{l}\text { Asylum } \\
\text { Seekers }\end{array}$ & $\begin{array}{l}\text { Returned } \\
\text { Refugees }\end{array}$ & $\begin{array}{l}\text { Internally } \\
\text { Displaced }\end{array}$ & $\begin{array}{r}\text { Returned } \\
\text { IDPs }\end{array}$ & Various & Total \\
\hline Africa & $3,523,250$ & 61,110 & 933,890 & 640,600 & $1,054,700$ & 36,990 & $6,250,540$ \\
\hline Asia & $4,781,750$ & 24,750 & 617,620 & $1,724,800$ & 10,590 & 149,350 & $7,308,860$ \\
\hline Europe & $2,608,380$ & 473,060 & 952,060 & $1,603,300$ & 370,000 & $1,279,000$ & $7,285,800$ \\
\hline $\begin{array}{r}\text { Latin America } \\
\& \text { Caribbean }\end{array}$ & 61,200 & 1,510 & 6,260 & - & - & 21,200 & 90,170 \\
\hline N. America & 636,300 & 605,630 & - & - & - & - & $1,241,930$ \\
\hline Oceana & 64,500 & 15,540 & - & - & - & - & 80,040 \\
\hline Total & $11,675,380$ & $1,181,600$ & $2,509,830$ & $3,968,700$ & $1,435,290$ & $1,486,540$ & $22,257,340$ \\
\hline
\end{tabular}

considerations in relation to questions of human security, organized crime involved in "people smuggling," and "economic migrants." The involvement of transnational organized crime has been described as the "dark side" of globalization. The UNHCr Policy Unit stated that "there are very few legal possibilities for refugees to enter the European Union and so the majority are required to attempt ever more clandestine forms of entry." 4

\section{Recognition of Asylum Seekers}

In order to understand the differential treatment of asylum seekers among countries, it is necessary to appreciate that, notwithstanding the UN Convention on the Status of Refugees (1951/1967), every state has its own legal and administrative procedures for dealing with asylum applicants. ${ }^{5}$ Furthermore, the interpretation of the un convention definition of a refugee varies considerably from one administration to another. The most important distinction is between those who use a convention definition for recognition only, and those that have introduced a form of "temporary asylum," which affords limited protection but does not give the right to permanent residence and eventual citizenship. ${ }^{6}$

When one considers the total number of asylum applications in Europe and North America for the whole of decade of the 1980 s, there were $2,247,600$ submissions, of which 421,730 (18.8 per cent) were given full convention recognition, and a further 103,150 (4.6 per cent) "humanitarian and other comparable status." The total for the decade 1990-9 was $5,549,560$ submissions, of which only 648,000 (11.7 per cent) were given full convention status. A further 475,260 (8.6 per cent) of the applicants were given "humanitarian and other comparable status." 7 In the 1980s, there were 923,870 rejections of asylum applications, compared with $3,194,460$ rejections in the whole of the decade 1990-9. It is evident that the last decade saw a huge increase in the number of applications for asylum, a decline in the proportion given full convention status, and an increase in the numbers and proportion who were give some form of "temporary asylum."

Given that at the end of each decade there were asylum applications still pending, or at an appeal stage, a slightly different picture emerges when only substantive decisions are taken into account. These are shown in table 2 for the main regions of Europe and for North America, comparing the situation in the 1980 s and the 1990s. The numbers of refugees increased by more than 50 per cent, and asylum seekers in industrialized countries by 300 per cent. ${ }^{8}$ When convention and other humanitarian status are combined, the acceptance rate fell from an average 36.2 per cent in the 1980 s to 26 per cent for the decade of the 1990s. Specific country rates varied. Germany's overall acceptance rate fell from 15 per cent to 11.5 per cent; the United Kingdom's overall rate was 78.9 per cent in the 1980 s but fell to 43 per cent in the 1990s, although an average of only 12.1 per cent were given full convention refugee status. The arrival of Kosova refugees in Britain in 1999 changed the pattern somewhat, as they were given more favourable treatment, 
raising the acceptance rate to 22 per cent in 1999. It fell to 12 per cent again in the first half of the year 2000. ${ }^{9}$ The pattern in Canada and the United States was different. Neither offered temporary asylum, although the Kosova situation was exceptional. The acceptance rate in the U.S. rose from 26.8 per cent in the 1980 s to an average of 43.9 per cent in the 1990 s. $^{10}$ Canada saw a similar increase in acceptance of asylum seekers as full refugees, from 36 per cent of applicants in the earlier period to 61.8 per cent in the subsequent decade (see table 2). In 1999 the average was 46 per cent acceptance, but there was considerable variation by country of origin, as shown in table 3 . (Table 3 shows the percentage accepted as convention refugees, as a proportion of claims finalized-the sum of positive and negative decisions, together with cases withdrawn and abandoned. When only cases actually adjudicated are considered, the overall acceptance rate, in 1999, was 58 per cent.)

Following the decline of the Soviet Union, the end of the cold war, the removal of many barriers to trade and commerce, the electronic linking of money markets, and the technological revolution in travel and communications that is associated with globalization, economically related international migration of the "proactive" type burgeoned. At the same time, political upheavals have generated ethnic conflicts and civil wars, giving rise to a rapid growth in reactive migration. Nevertheless, the main burden of support for victims of war, political persecution, and forced displacement from other causes remains in the developing countries of the Third World. The largest concentrations of refugees and others of concern to the UNHCR in 1999 were in Asia and Africa (with a combined total of 13.6 million). Europe's share increased to 7.3 million by 1999 , compared with 1.24 million in North America. The largest single concentrations were 1.8 million in Iran and 1.2 million in Pakistan.

The response in Europe and North America has been a tightening of regulations and new legislation designed to deter migration, interdict undocumented travellers, reinforce border controls, and penalize airlines, shipping companies, and truckers if they are discovered to have knowingly, or unknowingly, carried passengers who do not have a legal right of entry. Special efforts have been made to punish those involved in the organized smuggling of illegal immigrants across borders. Canada's Bill c-31, which died on the order paper as a result of a general election, was designed to "harmonize" its laws and administrative procedures with those of the United States and other countries. The concepts of a "safe third country" has been insti- tutionalized, requiring asylum seekers to apply in the first country they enter after flight from persecution.

\section{Discrimination or Persecution?}

There is a fine distinction in law between "a well-founded fear of persecution" and the experience of "discrimination." The former is generally interpreted to mean a life-threatening situation, or one involving torture, unjust imprisonment, or exile. Furthermore, claimants must show that they cannot rely on the protection of the state from which they have come, whose agents may be the source of the persecution. Problems of interpretation of the uN Convention arise when non-state agents of persecution are involved. ${ }^{11}$

The Roma in central Europe provide an interesting case study. There is no doubt that historically they have been victims of individual and systemic discrimination in many countries and that this discrimination persists to the present day. ${ }^{12}$ It may even have been exacerbated by the economic crises that many former Communist countries have experienced since the end of the cold war. Following a television broadcast in the Czech Republic and Slovakia that described Canada as a "safe haven" for the Roma, there was a sudden surge of asylum applications from that region in 1998. (It cannot be assumed that all applications from these countries were Roma, but a high proportion were.) In order to stem the flow, Canada subsequently imposed visa requirements on travellers from countries in central and eastern Europe. The results of asylum applications in 19979 for the Czech Republic, Hungary, and Slovakia are shown in table 4. The Canadian refugee determination system was more sympathetic to such claims than other countries, such as Germany and the United Kingdom.

Courts in Britain held that, in the case of the Roma, states such as the Czech Republic and Slovakia provide a measure of protection for the Roma (even when neglecting to enforce their own laws in this respect). Consequently, Romany asylum seekers from central Europe have generally failed to establish a claim to refugee status. The issue was judicially reviewed in the British House of Lords in the case of Horvath v. Secretary of State for the Home Department. ${ }^{13}$ The appellant was a citizen of the republic of Slovakia, where he lived with his wife and child and other members of his family. On October 15, 1997, he arrived in the United Kingdom with his wife and child and claimed asylum. He said that he feared persecution in Slovakia by skinheads, against whom the Slovak police were failing to provide protection for Roma. He also said that, along with other Roma, he had been unable to find work, that he had 


\begin{tabular}{|c|c|c|c|c|}
\hline \multicolumn{5}{|c|}{$\begin{array}{r}\text { Table 2: Percentage Recogniton of Asyl } \\
\text { Europe and North America }\end{array}$} \\
\hline & \multicolumn{2}{|c|}{$1980-9$} & \multicolumn{2}{|c|}{ 1990-9 } \\
\hline Region & Convention & Total Recognized" & Convention & Total Recognized" \\
\hline Eastern Europe & 100.0 & 100.0 & 26.8 & 35.1 \\
\hline Northern Europe & 35.8 & 83.8 & 7.6 & 49.4 \\
\hline Southern Europe & 38.6 & 38.6 & 8.2 & 10.7 \\
\hline Western Europe & 27.2 & 28.7 & 11.4 & 18.0 \\
\hline Total Europe & 29.2 & 37.6 & 10.8 & 23.3 \\
\hline European Union & 30.5 & 37.7 & 11.1 & 21.4 \\
\hline North America & 28.4 & 28.4 & 53.4 & 53.4 \\
\hline Average Per cent & 29.1 & 36.2 & 15.0 & 26.0 \\
\hline Number of Decisions & & $1,448,750$ & & $4,317,720$ \\
\hline
\end{tabular}

not been afforded the normal public facilities as to his marriage and schooling for his child, and that in these respects he was being discriminated against. He maintained that he was afraid that if he and his family were returned to Slovakia, as Roma, they would again be attacked by skinheads. They believed that they would not get protection from the police. In the course of the hearing it was stated,

This purpose has a direct bearing on the meaning that is to be given to the word "persecution" for the purposes of the Convention. As Professor James C. Hathaway, The Law of Refugee Status (Butterworths, 1991) p. 112 has explained, "persecution is most appropriately defined as the sustained or systemic failure of state protection in relation to one of the core entitlements which has been recognised by the international community." At p. 135 he refers to the protection which the Convention provides as "surrogate or substitute protection", which is activated only upon the failure of protection by the home state. On this view the failure of state protection is central to the whole system. It also has a direct bearing on the test that is to be applied in order to answer the question whether the protection against persecution which is available in the country of his nationality is sufficiently lacking to enable the person to obtain protection internationally as a refugee. If the principle of surrogacy is applied, the criterion must be whether the alleged lack of protection is such as to indicate that the home state is unable or unwilling to discharge its duty to es- tablish and operate a system for the protection against persecution of its own nationals. ${ }^{14}$

After arguments for and against deportation were heard, one judge concluded and the others agreed,

Where the allegation is of persecution by non-state agents, the sufficiency of state protection is relevant to a consideration whether each of the two tests-the "fear" test and the "protection" test-is satisfied. The proper starting point, once the tribunal is satisfied that the applicant has a genuine and well-founded fear of serious violence or ill-treatment for a Convention reason, is to consider whether what he fears is "persecution" within the meaning of the Convention. At that stage the question whether the state is able and willing to afford protection is put directly in issue by a holistic approach to the definition which is based on the principle of surrogacy. I consider that the Tribunal was entitled to hold, on the evidence, that in the appellant's case the requirements of the definition were not satisfied. I would refuse the appeal. ${ }^{15}$

There are many examples of discrimination (including those experienced by the First Nations in Canada) that fall short of "persecution" in the un convention sense of that term.

The evidence suggests that, in Europe particularly, there is a media-promoted and popular prejudice against the growing number of asylum applicants. Government actions to deter, interdict, and deport undocumented travellers have been described as a form of presumptive refoulement. ${ }^{16} \mathrm{~A}$ 


\section{Table 3: Asylum Applicants in Canada 1999 \\ Major Source Countries}

\begin{tabular}{|c|c|c|}
\hline Country & Finalized $^{*}$ & Per cent Accepted \\
\hline Afghanistan & 448 & 92 \\
\hline Somalia & 694 & 76 \\
\hline Sri Lanka & 3,091 & 76 \\
\hline Yugoslavia & 320 & 75 \\
\hline Iran & 942 & 70 \\
\hline Turkey & 320 & 68 \\
\hline Algeria & 735 & 67 \\
\hline Albania & 366 & 66 \\
\hline DR Congo & 1,060 & 62 \\
\hline Columbia & 309 & 50 \\
\hline Pakistan & 1,912 & 50 \\
\hline Russia & 739 & 48 \\
\hline China & 1,757 & 34 \\
\hline Romania & 464 & 29 \\
\hline India & 1,175 & 25 \\
\hline Argentina & 135 & 22 \\
\hline Mexico & 1,347 & 22 \\
\hline Nigeria & 593 & 20 \\
\hline Costa Rica & 371 & 9 \\
\hline Hungary & 955 & 8 \\
\hline Top 20 & 17,733 & 50 \\
\hline All others & 10,196 & 40 \\
\hline Total & 27,929 & 46 \\
\hline
\end{tabular}

Source: Canada Immigration and Refugee Board number of recommendations have been made, designed to establish the right to asylum as a core value, to make the principle of non-refoulement absolute, and to protect people from exploitation by unscrupulous criminals involved in people smuggling. It remains to be seen whether any of these recommendations will be implemented.

\section{Conclusion}

The Un Convention on the Status of Refugees (1951/1967) was a cold-war instrument that has proved inappropriate to deal with the crises of the late twentieth and early twentyfirst centuries. The possibility of a new more humanitarian convention receiving the necessary approval at this time seems unlikely. Ad hoc measures to cope with immediate crises, such as those that have occurred in the former Yugoslavia, are likely to persist. Arguably, the post-cold war global regime uses "humanitarian intervention" as an ideology to justify the use of military force. It uses "the language of human rights to legitimise a range of dubious practises." ${ }^{\prime 17}$ NATO countries have adopted the doctrines of "humane deterrence," designed to limit the number of asylum seekers arriving, and "instrumental humanitarianism" as a pragmatic response to the militar-ization of refugee camps and other crises. Some refugee flows may even be seen as threats to international security, thereby invoking intervention by the un Security Council, or by NATO. There is a "clash of norms" in current refugee policies that makes the implementation of an idealistic, ethically based, humanitarian program very difficult. ${ }^{18}$

The question remains, Is the treatment of refugees and asylum seekers in wealthier industrial countries sufficiently negative to be described as racist? Have we created a system of "global apartheid" designed to exclude people simply because of their ethnicity? The answer would seem to be yes and no. Europe and North America appear to be willing to accept "genuine" refugees from Africa and Asia, together with persons of colour, or other religions, as long as the need is dire and the numbers are small enough not to be perceived as a threat to the livelihood, or to the traditional ways of life, of the members of the receiving country. At the same time, the fear of overwhelming numbers has led to draconian measures that have a differential impact on those in peril. As Aiken rightly suggested, in this new millennium "the project of anti-racism" remains a "work in progress." ${ }^{19}$ Meanwhile, some comfort may be drawn from the Canadian example where the record of approval of asylum applications is more generous than that of most European countries. (The UNHCR praised Canada for its adoption of a "fast track" procedure for processing 


\section{Table 4: Asylum Applications 1997-9}

\section{Ratio of Convention Refugee Recognition to} Number of Decisions

\begin{tabular}{|c|c|c|c|c|}
\hline Origin & $\begin{array}{c}\text { Country of } \\
\text { Asylum }\end{array}$ & 1997 & 1998 & 1999 \\
\hline \multirow[t]{4}{*}{$\begin{array}{r}\text { Czech } \\
\text { Republic }\end{array}$} & & & & \\
\hline & Canada & 19:296 & $739: 1,053$ & $120: 170$ \\
\hline & Germany & 0:100 & $0: 67$ & $0: 0$ \\
\hline & U.K. & $0: 210$ & $0: 180$ & $0: 0$ \\
\hline \multirow[t]{4}{*}{ Hungary } & & & & \\
\hline & Canada & $8: 60$ & $153: 397$ & $70: 450$ \\
\hline & Germany & $1: 33$ & $0: 25$ & $0: 0$ \\
\hline & U.K. & $0: 0$ & $0: 5$ & $0: 0$ \\
\hline \multirow[t]{4}{*}{$\begin{array}{r}\text { Slovak } \\
\text { Republic }\end{array}$} & & & & \\
\hline & Canada & $0: 1$ & $5: 25$ & $0: 0$ \\
\hline & Germany & $0: 416$ & $0: 301$ & $0: 240$ \\
\hline & U.K. & $0: 375$ & $0: 325$ & $0: 0$ \\
\hline
\end{tabular}

urgent asylum cases, and for "ground-breaking guidelines" on gender-related persecution..$^{20}$ There remain controversial questions about documentation, interdiction, and the involvement of organized crime in people-smuggling. It is hoped that any future legislation and administrative practice will not be retrograde in this respect, although the new Bill c-11 has the potential of making it harder for "genuine" refugees to reach this country and be treated fairly.

\section{Notes}

1. Anthony H. Richmond, Global Apartheid: Refugees, Racism and the New World Order (Don Mills, Ont.: Oxford University Press, 1994), 208.

2. Sharryn Aiken, "Racism and Canadian Refugee Policy." Refuge 18, no. 4 (1999): 7.

3. UNHCR, Refugees and Others of Concern to the UNHCR: 1999 Statistical Overview (Geneva: UNHCR, 2000), 15.

4. John Morrison and B. Crosland, The Trafficking and Smuggling of Refugees: The End Game in European Asylum Policy (Geneva: UNHCR Policy Unit, 2000).

5. J. C. Hathaway and J. A. Dent, Refugee Rights: Report of a Comparative Survey (Toronto: York Lanes Press, 1995).
6. Howard Adelman and C. M. Lanphier, eds., Refuge or Asylum? A Choice for Canada (Toronto: York Lanes Press, 1990), o; Adam Roberts, "More Refugees, Less Asylum: A Regime in Transformation." Journal of Refugee Studies 11, no. 4 (1998): 375-95.

7. UNHCR, Refugees and Others of Concern to the UNHCR: 1999 Statistical Overview (Geneva: UNHCR, 2000).

8. In the first six months of 2000 there were 186,000 asylum applications filed in the European Union, 20 per cent of which were made in each of Germany and the U.K., and 11 per cent in the Netherlands (UnHCr, The State of the World's Refugees [Geneva: UNHCR, 2000]).

9. Anthony H. Richmond, "Refugees and Asylum Seekers in Britain: UK Immigration and Asylum Act, 1999." Refuge 19, no. 1 (2000): 35-42.

10. The figures for the U.S. do not take into account the interdiction program, introduced in 1981, that prevented many Haitians from reaching American shores. The Haitian Refugee Act, 1998, allowed those who had arrived in the U.S. before December 31,1995, to obtain permanent residence, but interdiction at sea continued (UNHCR, The State of the World's Refugees [Geneva: UNHCR, 2000], 177).

11. UNHCR, UNHCR Global Report, 1999 (Geneva: UNHCR, 2000), 163.

12. Holly Cartner, Destroying Ethnic Identity: The Persecution of Gypsies in Romania (New York: Helsinki Watch, 1991); David Crowe, A History of Gypsies in Eastern Europe and Russia (New York: St. Martin's Press, 1995). European Roma Rights Centre. Roma Rights. Vols. 1-3. European Roma Rights Centre, 19982000.

13. House of Lords. July 2000. Horvath v. Secretary of State for the Home Department.

14. Ibid.

15. Ibid.

16. Morrison and Crosland, The Trafficking and Smuggling of Refugees, 6 .

17. B. S. Chimni, Globalisation, Humanitarianism and the Erosion of Refugee Protection (Oxford: Refugee Studies Centre, Queen Elizabeth House, 2000), 2.

18. J. S. Goodwin-Gill and J. Kumin, Refugees in Limbo and Canada's International Obligations (Toronto: Caledon Institute of Social Policy, 2000). Myron Weiner, "The Clash of Norms: Dilemmas in Refugee Policies." Journal of Refugee Studies 11, no. 4 (1998): 433-53.

19. Aiken, "Racism and Canadian Refugee Policy," 7.

20. UNHCR, UNHCR Global Report, 1999 (Geneva: UNHCR, 2000), 181.

Anthony H. Richmond, F.R.S.C., is emeritus professor of sociology and senior scholar, Centre for Refugee Studies, York University, Toronto. He is author of Global Apartheid: Refugees, Racism and the New World Order. 